\title{
Ilé Òsùmàrè Aràká Àse Ògòdó ${ }^{1}$
}

\section{Marta Bogéa}

Professora no Departamento de Projeto da Faculdade de Arquitetura e Urbanismo da Universidade de São Paulo (FAUUSP)

Contato: mbogea@usp.br

\section{RESUMO}

Este texto analisa o projeto proposto por Marcelo Ferraz e Francisco Fanucci (Brasil Arquitetura) tendo em vista a preservação simbólica e cultural, através da renovação arquitetônica e paisagística do Terreiro Baiano de Candomblé Ilê Axé Oxumarê, situado na cidade de Salvador, considerado um dos mais antigos centros de culto afro-brasileiro da Bahia tombado pelo IPHAN em 2013.

Palavras-chave: Terreiro de Oxumarê, Brasil Arquitetura, Projeto.

\section{ABSTRACT}

This text analyzes the project proposed by Marcelo Ferraz and Francisco Fanucci (Brasil Arquitetura) in view of the symbolic and cultural preservation, through the architectural and landscape renovation of Terreiro Baiano of Candomblé Ilê Axé Oxumarê, located in the city of Salvador, considered one of the most former centers of Afro-Brazilian cult of Bahia registered by IPHAN in 2013.

Key-words: Terreiro of Oxumarê, Brasil Arquitetura, Project. 


\section{Movimento: legado e transformaçáo}

"O Conselho Consultivo do Patrimônio Cultural aprovou nesta quarta-feira (27) o tombamento do Terreiro Baiano de Candomblé Ilê Axé Oxumarê. "’

A solicitação de tombamento da Casa de Òsùmàrè, considerada um dos mais antigos centros de culto afro-brasileiro da Bahia, foi feita em 18 de setembro de 2002 pelo sacerdote Babalorixá Agoensi Danjemin, supremo dirigente na época da Casa de Òsùmàrè.

Antecede o reconhecimento nacional, o reconhecimento local: no ano de 2004, o terreiro foi tombado pelo Instituto do Patrimônio Artístico e Cultural da Bahia (IPAC) como patrimônio material e imaterial.

De acordo com o IPHAN, a contínua erosão do solo da encosta na área do terreiro - situado no alto de uma colina na Avenida Vasco da Gama, na Federação - foi agravada nos últimos anos, causando deslizamentos de terra e queda de árvores sagradas, impedindo a celebração de rituais centenários diante dos altares externos. ${ }^{3}$

A partir da urgência de consolidação da encosta, o projeto de salvaguarda do conjunto propóe sua preservação física e simbólica através da realização de patamares e muros de contenção e da ampliação do conjunto edificado com a criação de áreas de hospedagem, cozinhas, depósitos, residências, auditório e memorial, além do grande espaço de festas e convívio. ${ }^{4}$ (figura 01 )

Oportunidade singular que permite, em sintonia com o Orixá da casa, pôr as coisas em movimento "Oxumarê é a mobilidade e a atividade. Uma de suas obrigaçôes é a de dirigir as forças que produzem o movimento" (VERGER, 1997, p.206).

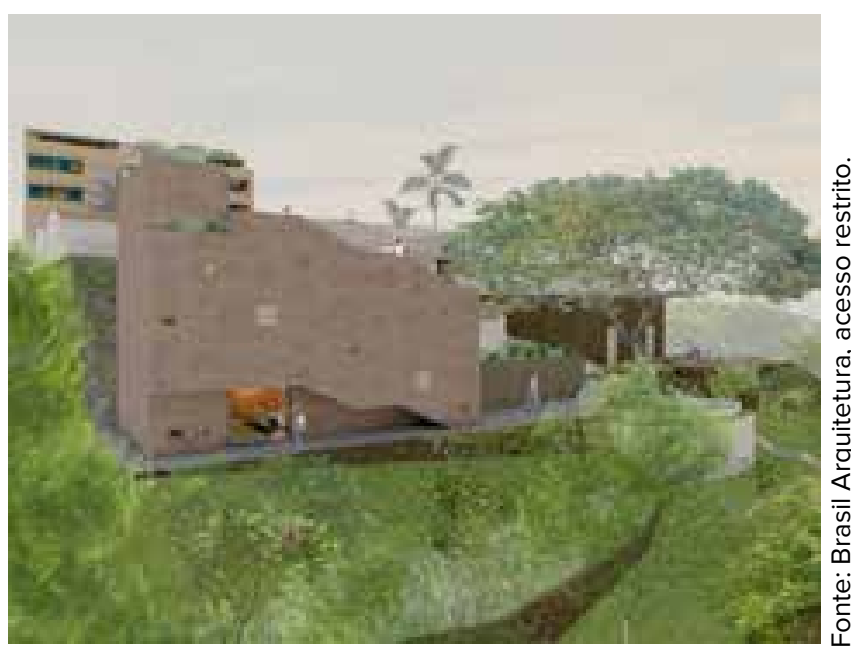

Figura 01: Imagem do anteprojeto, mata e memorial.

Esse artigo analisa a ação arquitetônica buscando compreender as razóes físicas e simbólicas que presidem o projeto de renovação arquitetônica do Ilê Axé Oxumarê.

\section{Natureza dos cultos e natureza sagrada, a mata e a água}

Quem é ateu e viu milagres como eu / Sabe que os deuses sem Deus / Não cessam de brotar, nem cansam de esperar / E o coração que é soberano e que é senhor / Não cabe na escravidão, não cabe no seu não / Não cabe em si de tanto sim / É pura dança e sexo e glória, e paira para além da história

Ojuobá ia lá e via / Ojuobahia / Xangô manda chamar Obatalá guia / Mamãe Oxum chora lagrimalegria I Pétalas de Iemanjá Iansã-Oiá ia / Ojuobá ia lá e via / Ojuobahia / Obá

Milagres do Povo 5 (1981) Caetano Veloso

O santuário de Oxumarế ${ }^{6}$ tem permitido, junto a outros terreiros, um perceptível "milagre" na cidade de Salvador na Bahia: através dos cultos do Candomblé a proteção das matas onde estão instaladas 


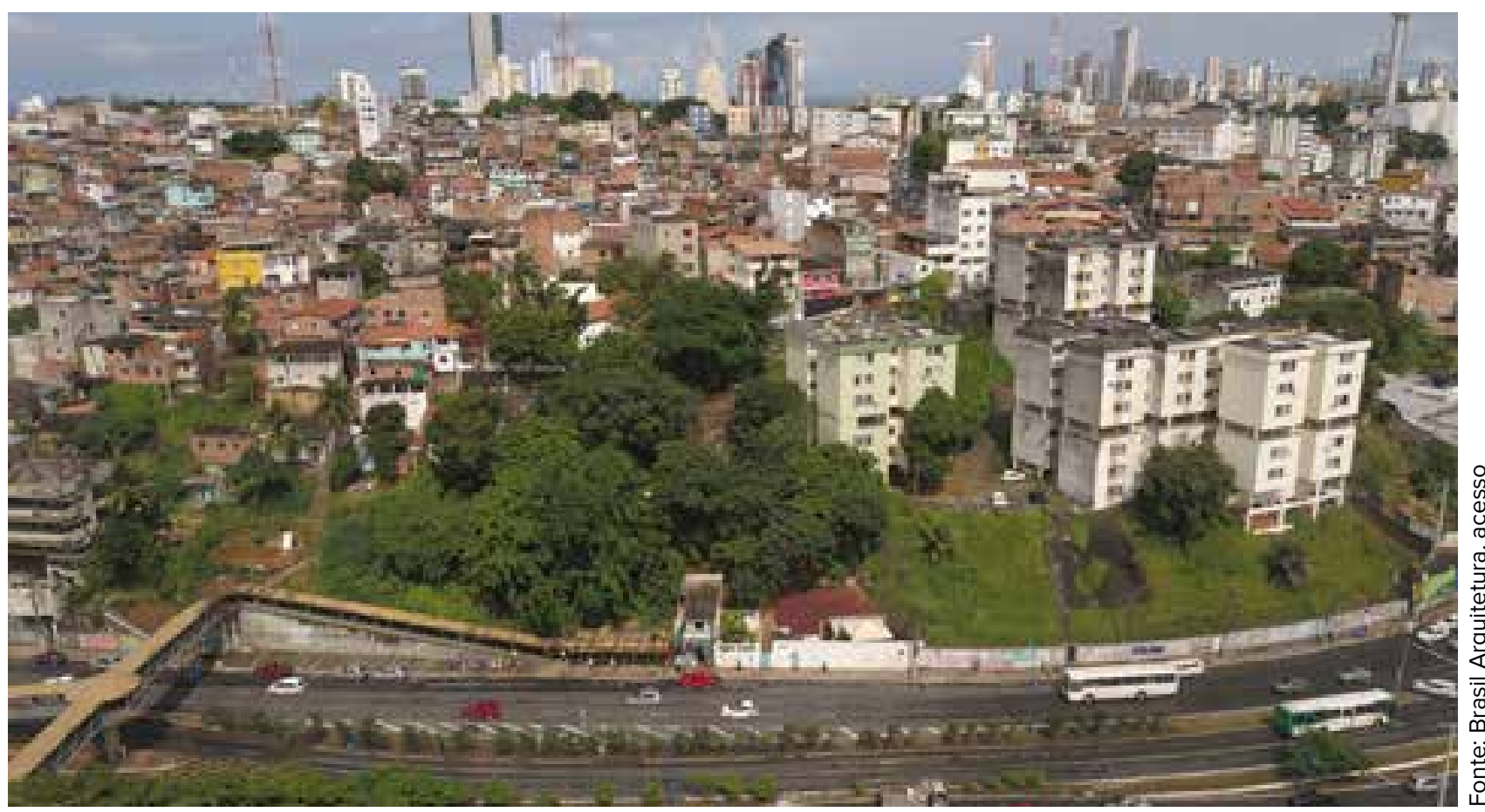

Figura 02: Foto aérea a partir da Avenida Vasco da Gama.

suas casas. Náo à toa um dos subtítulos do caderno de apresentação do estudo realizado pelo Brasil Arquitetura para aprovação no IPHAN é "A geografia como patrimônio" no qual os arquitetos explicitam a presença do modelo de ocupação histórico:

(...) a mancha verde do Terreiro de Oxumarê na encosta da Vasco da Gama representa o que foi ao longo de séculos a lógica da ocupação do território acidentado de Salvador. Qual seja: pequenas construções nas cumeadas dos morros junto aos caminhos de acesso, ladeadas pela vegetação exuberante assentada em declive até os vales dos rios e córregos. Este modelo de ocupação foi desaparecendo nas últimas décadas, foi sendo destruído pelo processo de urbanização desenfreado e massivo. E o Terreiro de Oxumarê conserva esta característica original e lógica de se mediar construção com preservação da natureza. ${ }^{7}$ (figura 02)

Ampliada a abrangência do mapa, pode-se reconhecer na vizinhança a mesma proteção no Terreiro Ilê Iyá Omi Axé Iyamassê, Terreiro do Gantois e no Candomblé Casa Branca. Todos os três terreiros estáo entre os seis bens tombados e identificados no Grupo de Trabalho Interdepartamental para Preservação do Patrimônio Cultural de Terreiros (GTIT) ${ }^{8}$.

Vale observar que a proteção da mata se deve à compreensão de sua dimensão sagrada intensamente presente no cotidiano dos cultos - não são matas contemplativas, mas espaços sagrados de uso na vida dos terreiros. Os textos apresentados no GTIT apresentam claramente essa dimensão.

Ao descrever a premissa de tombamento do Terreiro Casa Branca do Engenho Velho ${ }^{9}$ - Salvador (BA), inscrito nos livros do Tombo Histórico e Arqueológico, Etnográfico e Paisagístico em 1989, pode-se 
reconhecer os traços que esses sítios guardam em comum - no caso do Engenho Velho o tombamento da área de $6.800 \mathrm{~m}^{2}$ considera "edificaçóes, árvores e seus principais objetos sagrados". O texto descritivo do IPHAN sobre o bem esclarece:

Situado em terreno com declive, o terreiro possui uma edificação principal (a Casa Branca) que domina todo o sítio e centraliza o culto, com as diversas Casas de Santo (Ilê Orixá) distribuídas à sua volta, em meio à vegetação ritual (o Mato) com imensas árvores sagradas e outros assentamentos, além das habitações da comunidade local. Esta espacialidade náo pode ser entendida separadamente dos ritos que aí se desenvolvem e, apesar de todas as mutilaçóes e transformaçóes sofridas pelo Terreiro ao longo do tempo, não foram descaracterizados, devido ao forte apego da comunidade às tradiçóes. $\mathrm{O}$ simbolismo dos elementos componentes do conjunto e as características do culto devem determinar as diretrizes de sua preservação. ${ }^{10}$

Em outros termos, mas com a mesma perspectiva, o texto sobre o Terreiro do Axé Opô Afonjá, tombado pelo IPHAN em 2000, observa também a presença da mata:

O terreiro ocupa uma área de cerca de 39.000 metros quadrados (m2) e está localizado no Cabula, em Salvador (BA). (...) As edificaçóes de uso religioso e habitacional ocupam cerca de $1 / 3$ do total do terreno, em sua parte mais alta e plana, sendo o restante ocupado pela área de vegetação densa que constitui, nos dias de hoje, o único espaço verde das redondezas ${ }^{11}$.

Reconhecer a natureza e preservá-la é parte do Candomblé. Uma convicção expressa por Lody:

Sem natureza não há candomblé, visto a importância das águas, das folhas, das matas, na busca e um perfeito equilíbrio ecológico que verdadeiramente é a unidade e a essência dos orixás, dos inquices, dos voduns. (LODY In: CARNEIRO, 2008, p.170)

Importante entender que náo se trata, portanto, de preservação apenas material, mas sobretudo da preservação do valor simbólico que protege a natureza e a materialidade envolvida.

Ao preservar a mata preserva-se uma importante tradição em relação às árvores. Em Oxumarê, relatam os arquitetos:

A "mata escura", como era conhecida até ao início do século XX, deverá ser recuperada e adensada, recebendo caminhos em suaves rampas para passeios e contemplação da natureza e do sagrado. De cima abaixo, ou de baixo acima, pela mata escura, a longa escada representará a cobra/caminho a cruzar as terras sagradas de Ilê Oxumarê. ${ }^{12}$

A paisagem natural, portanto, é território sagrado. Aspecto reconhecido nos textos de antropologia como pode ser verificado na convergência de análise em Roger Bastide e Edison Carneiro. Conforme Bastide:

Vê-se também muitas vezes nas moitas emaranhadas, uma ou duas árvores cujos galhos trazem pendurados pedaços 
de pano branco chamado oja, e ao pé dos quais se encontram garrafas, pratos, recipientes de toda espécie. Uma dessas árvores, a gameleira-branca é identificada com o Iroco, a árvore sagrada dos africanos, e é preparada exatamente como se prepara uma pedra ou uma filha-de-santo, isto é, fixando-se dentro dela a divindade; daí por diante, tornase objeto de culto, não pode mais ser tocada por ninguém, e se lhe cortassem os galhos, deles correria sangue. (1978, p.75)

Em Carneiro:

Entre as árvores sagradas encontramse, especialmente, a gameleira-branca, morada do deus Loco, excelente lugar para se deixarem oferendas, e talvez outras, como, por exemplo, Zacaí e Umpanzo, no Bate-Folha, sempre com um pano branco ou vermelho amarrado, com um grande laço, no tronco, e restos de velas ali, acessas pelos devotos. (2008, p.38)

Além da mata, a água também é natureza protegida, porque sagrada, constitui outro importante elemento para o candomblé. Bastide, ao descrever os terreiros, observa que muitos deles possuem uma fonte sagrada, "onde as filhas-de-santo vão tomar seus banhos, de onde se tira a água para a lavagem das pedras, e que se dá de beber como um teste de 'pureza do corpo' (se a pessoa manteve relaçóes sexuais na noite anterior, a água fá-la adoecer). Estas fontes têm nomes diferentes, conforme a divindade que a protege: fonte de Oxum, água de Xangô, bica de Oxalá...” (1978, p.75)
Carneiro descreve o uso das águas nas cerimônias:

(...) a água de Oxalá - cerimônia que inaugura as festas da casa - é mesmo uma divinização desse elemento $\mathrm{da}$ natureza; a quartinha de barro dos orixás deve ter a água mudada cada dia e as iaôs sáo obrigada pela tradiçáo a, durante o noviciado, tomar banho todos os dias na fonte mais próxima, antes da aurora; os ogãs em vista devem, antes de transpor os umbrais da casa, beber um pouco d'água e atirá-la, depois, nos lados e na frente da porta. (2008, p.42-43)

Bàbá Egbé Leandro relata aspectos do rito dos banhos sagrados no Ilê Axé Oxumarê:

O poço foi construído pelos escravizados, é bem antigo, feito de pedra, tem uns oito ou nove metros de profundidade, mas não há bomba, é bem fundo, mas se usa corda para buscar a água. É preciso entender que qualquer oferenda é uma manipulação de energia, não deixa de ser um sacrifício; para pegar água nessa fonte: primeiro se acorda a água, (...), é preciso um despertar espiritual, joga uma pedrinha de calcário... aí tira a primeira água e dá para Exu, joga na terra, para a água fresca refrescar o solo quente, para acalmar, apaziguar o ambiente. (...). Se puxa com a corda o balde, é uma dedicação além do valor da água, porque é vida e tem energia em movimento. ${ }^{13}$

Foi para preservar as árvores sagradas, a fonte e o caminho para fonte através da mata que mãe Nilzete se 
interpôs para impedir a desapropriação de terras do Terreiro em 1988, que seriam tomadas para construçáo da passarela para pedestres na Avenida Vasco da Gama, visando interligar o bairro da Federaçáo com o bairro do Engenho Velho de Brotas. Segundo texto disponível no site do Terreiro:

A construçáo idealizada pela prefeitura iria apropriar-se de uma grande área da Casa de Òsùmàrè, destruindo a fonte de água - elementar para o culto aos Òrìsà - e a árvore İrókò, o Pai de todas as árvores. Mãe Nilzete e Bàbá Pecê passaram a fazer plantáo nas escadarias do Terreiro, ao lado da árvore sagrada, lutando pela sua preservação, chegando mesmo a colocar-se em frente aos tratores para impedir a destruição da grande Árvore-Òrìsà. ${ }^{14}$

O projeto de implantação da passarela foi alterado, reconhecido o valor da defesa solicitada. Interessa observar que o Terreiro estabelece uma importante articulação urbana, permitindo, através da escadaria, transpor os diferentes níveis da encosta. A escadaria existente será mantida, levando à cota intermediária onde está instalado o Barracáo no mesmo nível do segundo acesso pela $2^{\text {a }}$ travessa Pedro Gama de Baixo e, após o Barracáo, um novo lance conecta de modo controlado o acesso à rua de trás, travessa Juruá em continuidade com rua Alto da Bomba (figuras 03 e 04).

\section{Açáo arquitetônica}

O anteprojeto de reforma da Casa de Oxumarê apresentado pelo Brasil Arquitetura foi aprovado para desenvolvimento e constitui material necessário para pactuar as transformaçóes em consonância com o

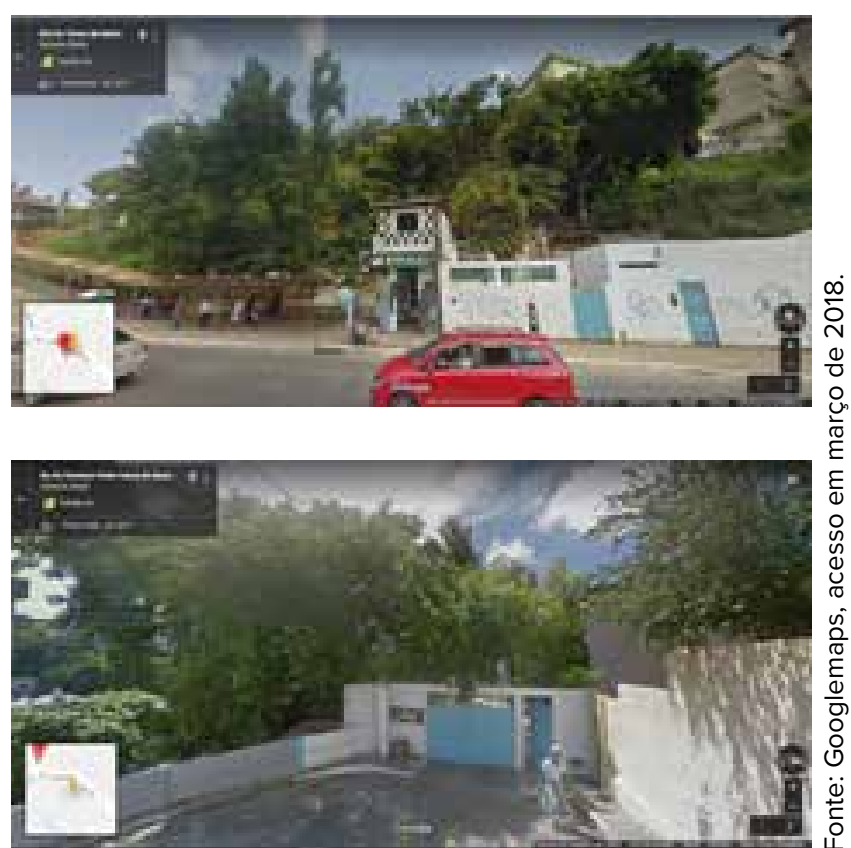

Figura 03 Avenida Vasco da Gama, com a atual borracharia, o portão azul de acesso à escadaria, a marquise da passarela de travessia da avenida;

Figura 04: acesso pela $2^{a}$ travessa Pedro Gama de Baixo.

nota: $O$ terceiro acesso é indisponivel para carros, portanto sem possibilidade de vista através do Googlemaps.

tombamento. O parecer técnico $n^{\circ} 0547 / 2017$ no qual constam como interessado Silvanilton Encarnação da Mata, Babalorixá da Casa de Oxumarê, e como bem o Terreiro de Candomblé - Casa de Oxumarè situado na Av. Vasco da Gama, n³43, Federação, Salvador - BA, aprova a consulta prévia para reformas e construçóes novas, considerando demolição de edificações recentes e irregulares que não agregam valor ao conjunto, reformas nas edificações que compóem o local e construção de novos edifícios que "de modo direto e indireto contribuirão para a preservação e divulgação da religião de matriz africana". (Figuras 05 e 06). 


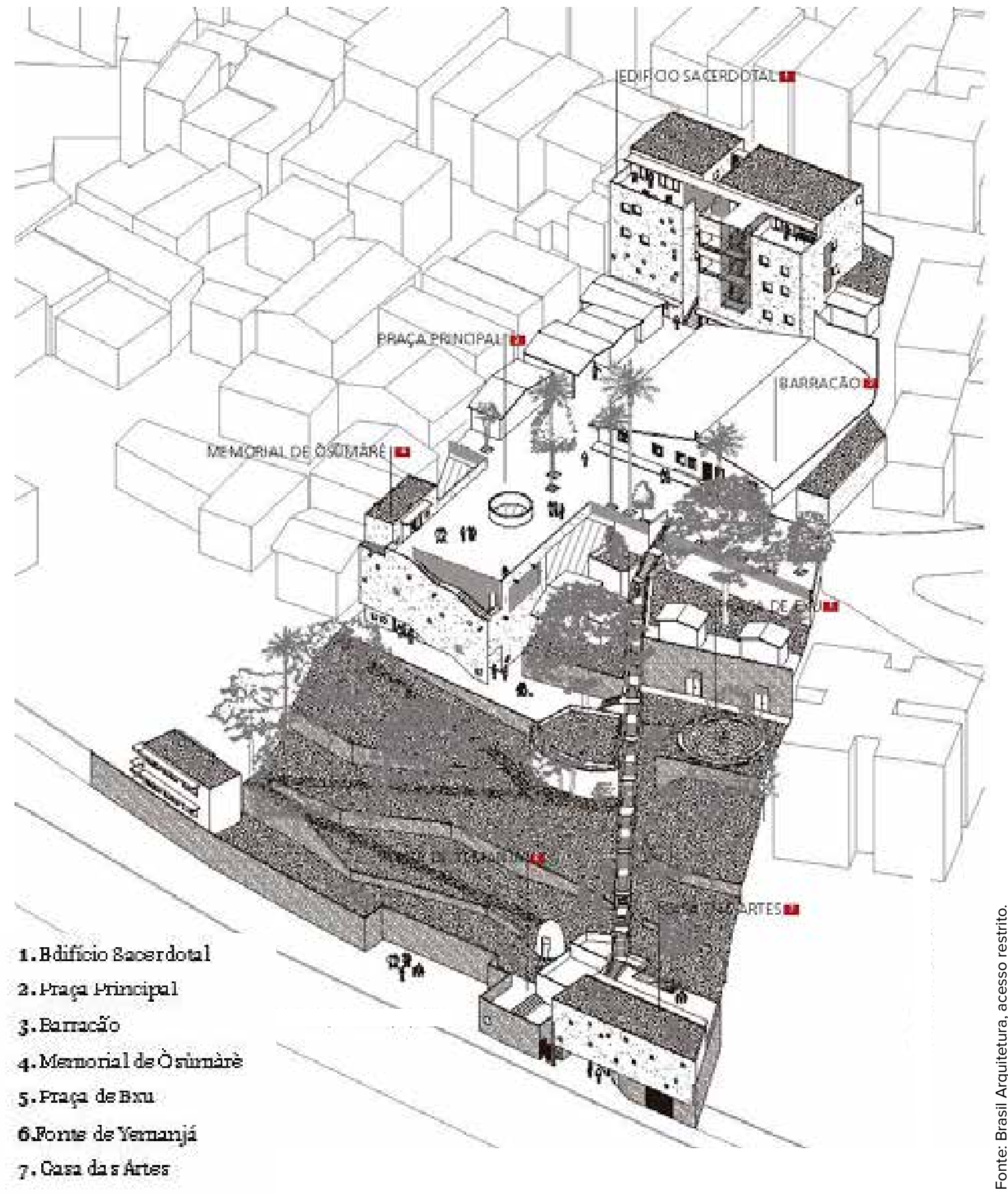

Figura 05: Isométrica identificando o conjunto como proposto.

Revista online do Departamento de Arquitetura e Urbanismo da Pontifícia Universidade Católica Puc-Rio - Rio de Janeiro Brasil Ano I- No I - ISSN 2446-7340 


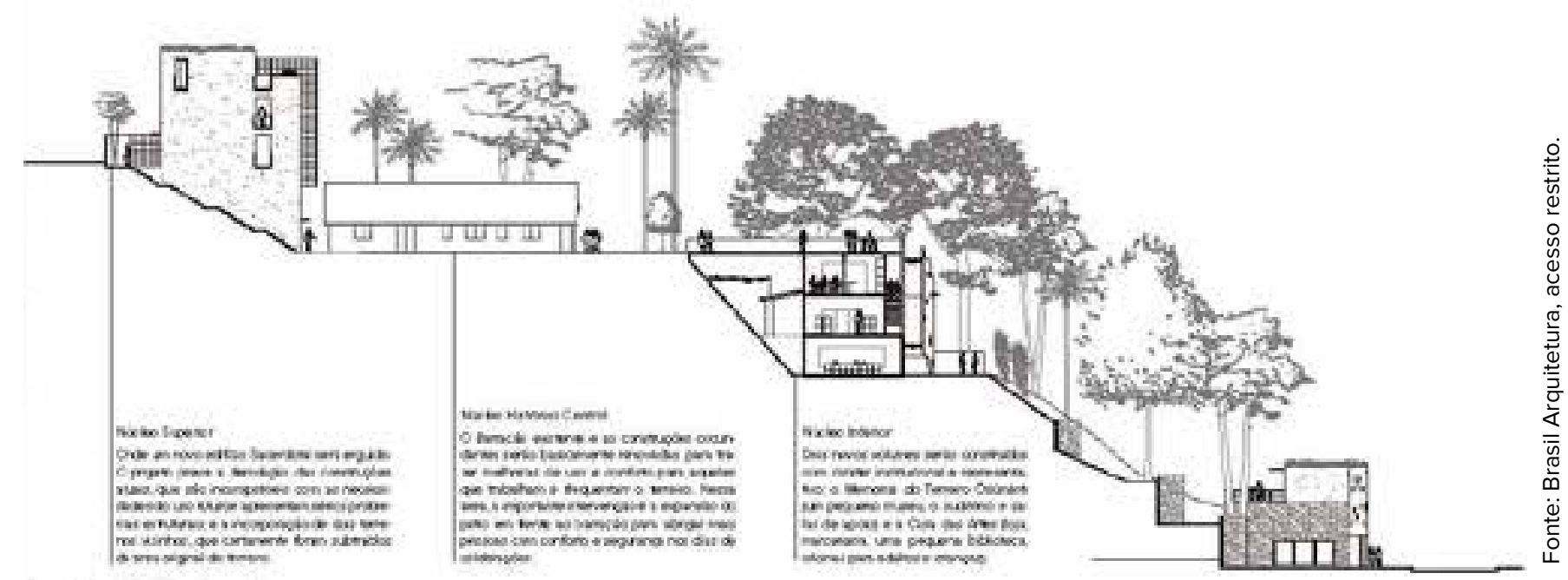

Figura 06: Corte identificando o conjunto como proposto.

Serão quatro novos edifícios:

I.Edifício Sacerdotal: com cinco pavimentos compreendendo cozinha industrial, banheiros, vestiários, lavanderia, alojamentos / apartamentos, residência do Babalorixá, administração e sala de reuniôes, voltado para a Travessa Juruá em continuidade com Rua Alto da Bomba;

II.Memorial: edificação de três pisos compreendendo auditório, sala de exposição, sala de apoio, banheiros, elevador e escadas, que tem a laje de cobertura como continuidade e ampliação da praça em frente ao Barracão;

III.Casa das Artes: edificação com três pisos destinada à execução de projetos sociais e culturais - como exemplo, atividades pedagógicas e oficinas de trabalhos manuais com foco nos saberes e ofícios tradicionais do candomblé -, voltada para Avenida Vasco da Gama;

IV.Apartamento Funcional: edificação de dois pavimentos para moradores, também voltado para mesma avenida.
Outros espaços serão reformados. Os Espaços Sagrados receberão adequação nas casas de santos, com a construção de mais duas delas, localizadas acima da Praça Exu e do Barracão. Importante observar que nesses espaços ocorrem sobretudo retirada de pequenos acréscimos feitos ao longo do tempo sem comprometimento em relação aos assentamentos originais (que têm função sagrada!). As reformas precisam ser criteriosas, pois, nos espaços sagrados, de acordo com o depoimento do Bàbá Egbé Leandro ${ }^{15}$, além do assentamento, os materiais usados na construçáo são pertinentes a cada Orixá e, portanto, referem-se também ao campo sagrado e simbólico.

$\mathrm{Na}$ proposta existem três significativas novas construçóes, que abrigam programas laicos: o espaço sacerdotal, a casa das artes e o memorial. Na conversa com Bàbá Leandro, sua descrição sintética através da maquete é esclarecedora e confirma a pertinência do partido adotado: "Tudo que é telhado de barro é sagrado". (Figura 07) A distinção em sintonia com os princípios de restauro atual - que recomenda distin- 
guir as novas intervençóes das construçôes existentes - nesse caso valoriza a singularidade desse lugar onde a vida vivida cotidianamente ocorre aproximada dos cultos e ritos sem, contudo, embaralhar suas distintas motivaçôes.

\section{Memória(s)}

A proteção da mata, assegurada pelos ritos, implica na resolução técnica de estruturação da encosta. Para tal operação, os arquitetos amparam-se em outra tradição, agora construtiva, que remonta às primeiras ocupaçóes de Salvador: os muros de arrimo em pedra, citados no caderno de estudo, e que, ainda hoje, são bastante presentes na paisagem da cidade histórica.

Aqui interessa o reconhecimento das razóes de preservação que se encontram no sítio a ser protegido e na sabedoria construtiva que usufrui de uma técnica presente e local nos modos dessa proteção. A mata, hoje na encosta precipitada pela erosão após construção da pista expressa, será redefinida em patamares com arrimos - os "mesmos" muros que o Brasil Arquitetura reconhece e valoriza no projeto para Vila Nova Esperança (2007), na Barroquinha

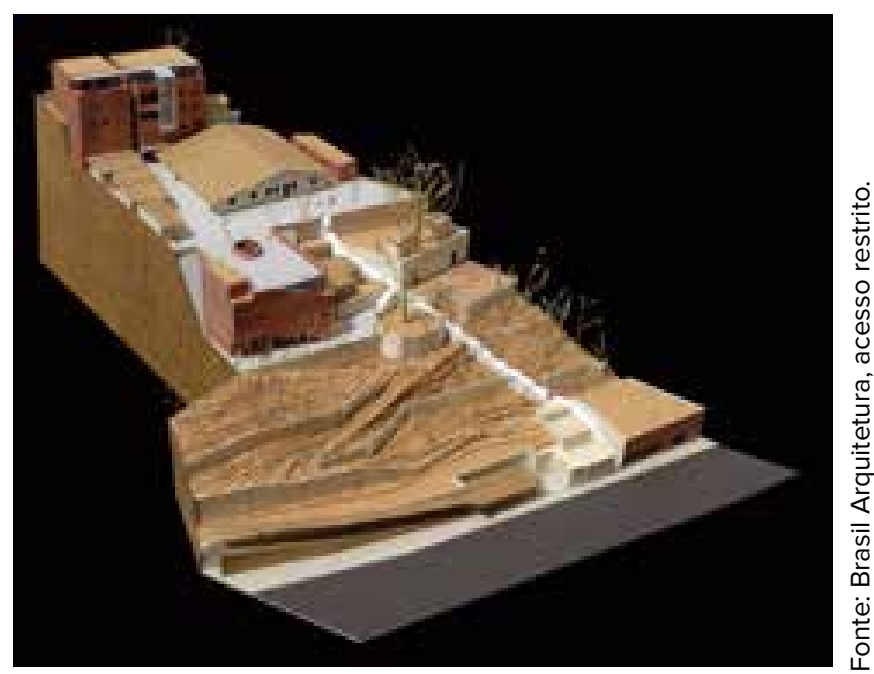

Figura 07: Fotografia da maquete. também em Salvador ${ }^{16}$ Lá os muros existentes são preservados e ampliados; aqui os muros são convocados diante do desafio de assentar a mata de modo a que a vida dos cultos ocorra em segurança.

Um gesto que ecoa um valor que não se encontra na contiguidade do objeto de preservação, mas com uma lógica de ocupação do território, de forma mais ampla, que considera o lugar onde esse objeto se instala. Preserva porque amplia certo saber, um modo muito reconhecido no patrimônio imaterial e que em arquitetura muitas vezes é pouco utilizado, tão atentos que ficamos à "coisa em si”. A preservação, nesse caso, não se dá apenas naquilo que está diante de nossos olhos, mas deve convocar o saber existente na região e que se quer manter como valor.

Um legado abrangente que olha também para Benim, na África, com a presença da terra e dos pedriscos nas construçóes e na figura de representação de Oxumarê.

Procuramos introduzir com nossa arquitetura elementos da natureza como a pedra nos muros de arrimo; a terra em diferentes tons (ocre e vermelho óxido de ferro) no reboco dos novos blocos, em contraste com o branco do leite de cal utilizado atualmente nas casas de santos; ainda a terra batida em pisos como a futura Praça de Exu; e pedriscos nos caminhos da mata. Elementos simbólicos deverão habitar os muitos nichos (rebaixos nas paredes e muros) do futuro bloco institucional (museu e auditório), a exemplo das figuras dos palácios de Abomei, no Benim. ${ }^{17}$

A representação de Oxumarê no Benim dá origem a um inédito elemento arquitetônico, desenhado espe- 
cificamente para os novos edifícios desse sítio: os cobogós oxumarê (figura 08) - que entrelaçam tradição arquitetônica (elemento cerâmico vazado), arquitetura moderna brasileira (ver, por exemplo, Parque Guinle, projeto de Lúcio Costa) e tradiçãoo africana.

Nos termos do candomblé, significa a preservação simbólica e cultural que não impede a renovação, desde que respeitados os valores sagrados, como se pode apreender com o entendimento da antropologia:

No dialeto dominante em candomblés baianos e na língua iorubá de que o termo deriva, axé (àsè) designa a sagrada força genesiática que "permite realizaçáo da vida [e] assegura a existência dinâmica.", pois "possibilita os acontecimentos e as transformaçōes" (LOPES, 2004 In: SERRA, 2002, p.1)

Vale observar o modo como a casa de Oxumarê realiza as cerimônias do primeiro mês do ano voltadas ao culto aos ancestrais e ao culto ao dinamismo. De acordo com seu calendário religioso,
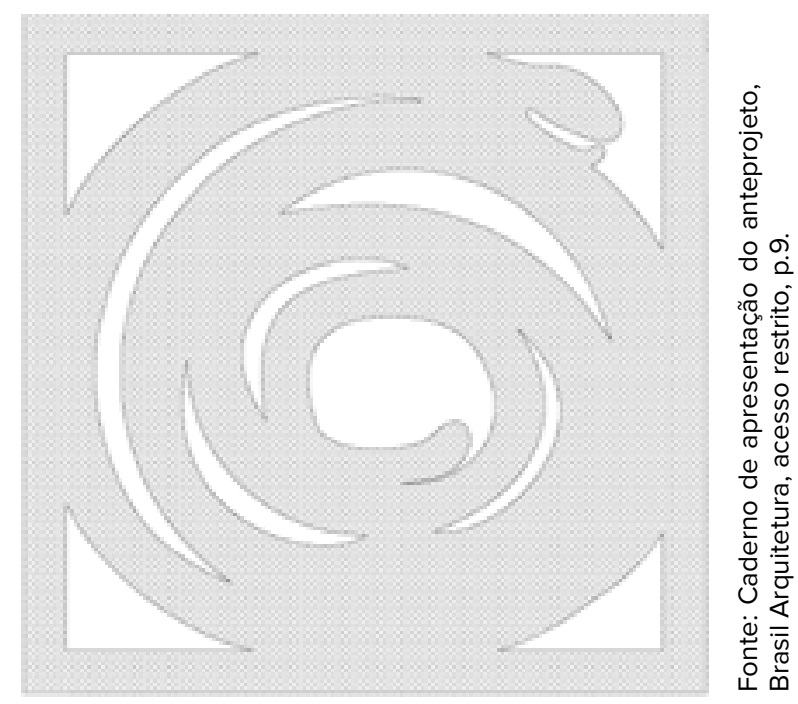

Figura 08: Cobogó Òsúmàrè desenhado para $o$ terreiro a partir de diversas representaçôes. ocorre uma homenagem aos ancestrais no domingo "antes da primeira sextafeira do ano” - "Orò Awón Esá, obrigação em homenagem aos ancestrais, dedicada especialmente a louvar os antepassados responsáveis pela fundação da Casa e do culto"-, e, na segunda-feira "antes da primeira sexta-feira do ano" - Ajòdún Orisà Esù - realizam-se "festividades em homenagem Esù, divindade do princípio e do dinamismo. ${ }^{18}$

A beleza, no contexto de abordagem deste artigo, reside na dupla condição de reconhecer o legado sem impedir o movimento e a transformação. Pois todo passado é no presente uma construçáo que póe o tempo em movimento.

As duas cerimônias são como uma espécie de preâmbulo ao início do ano que será marcado pela primeira sexta-feira do ano com a Cerimônia das Águas de Òsàlá - Àwón Omi Òsàlá - que ocorre como descrito:

$\mathrm{Na}$ noite que antecede a cerimônia, todos os abòrìsà (adoradores de Òrìsà) dormem no terreiro, sendo purificados através do Omi èrò (Água que acalma). Vestidos de branco, na madrugada (Ojúmómó) de sexta-feira, em silêncio absoluto, todos seguem em procissão a caminho da fonte sagrada de Òsàlá (Orísun Òsàlá), para carregar a água que será utilizada para lavar os objetos sagrados do grande Òrìsà e, através destas açôes, purificarem o corpo e alma. ${ }^{19}$

Volta à água, volta à mata, o reinício sagrado permite reconhecer o passado para seguir adiante, modo de convocação da memória e dos valores que permitem que cada um se reconheça dentro da história em co- 
mum. Traço mnemônico descrito pela neurociência:

Eu sou quem sou, cada um é quem é, porque todos lembramos de coisas que nos são próprias e exclusivas e não pertencem a mais ninguém. Nossas memórias fazem com que cada ser humano (...) seja um ser único, um indivíduo. A necessidade de interação entre membros da mesma espécie, ou entre diferentes espécies inclui, como elemento-chave, a comunicação entre indivíduos (...) procuramos laços (...) e com base em nossas memórias comuns formamos grupos: comarcas, tribos, povos, cidades, comunidades, países (...). (IZQUIERDO, 2011, p.12-13)

E, se por um lado, nossas memórias e as operações engendradas por elas nos dizem quem somos como indivíduos e como parte de um grupo, por outro, nos reinventamos também a partir desse processo. Pois:

Afinal, traduzir quer dizer não só verter a outro código, mas também transformar. Há algo de prestidigitação nessa arte que tem o cérebro de fazer memórias, de transformar realidades, conservá-las, às vezes modificá-las e revertê-las ao mundo real. (IZQUIERDO, 2011, p.20-21).

Um real habitável intrinsecamente associado à ideia de lembrança.

Michel de Certeau nos permite compreender este valor. A partir de uma entrevista com uma moradora da Croix-Rousse em Lião, concedida a Pierre Mayol, que diz que "estamos ligados a este lugar pelas lembranças (...). É pessoal, isto não interessaria a ninguém, mas enfim é isso que faz o espírito do bairro". Diante da frase, Certeau observa: "Só há lugar quan- do frequentado por espíritos múltiplos, ali escondidos em silêncio, e que se pode 'evocar' ou não. Só se pode morar num lugar assim povoado de lembranças (...) " (CERTEAU, 1994, p.189).

Essa abordagem, inscrita em "A invenção do cotidiano, no livro 1: Artes de Fazer", está em um trecho significativamente intitulado "Críveis e memoráveis: a Habitabilidade". Fala sobre lugares e passado, lembra que as paisagens se constituem lugares na medida em que sua materialidade abriga também fatos ocorridos indissociáveis de sua rememoração. (Figura 09)

$\mathrm{Na}$ casa de Oxumarê, trata-se de uma rememoração que levará à ancestralidade africana renovada pela dura realidade da constituição dos terreiros de candomblé no Brasil, que exige reinvenção de algumas bases, dentre elas, o assentamento para vários Orixás, característica singular dos terreiros brasileiros, em relação à matriz africana: "Existe em cada terreiro de candomblé, múltiplos orixás pessoais, reunidos em torno do orixá do terreiro, símbolo do reagrupamento, do que foi disperso pelo tráfico." (VERGER, 1997, p.33)

Verger explica essa diferença a partir do culto:

A diferença entre as cerimônias para os orixás na África e no Novo Mundo decorre, sobretudo, de que, na primeira evoca-se um só orixá durante uma festa celebrada em um templo reservado para ele, enquanto no Novo Mundo vários orixás são chamados em um mesmo terreiro durante uma mesma festa. E ainda na África tal cerimônia é celebrada geralmente pela coletividade familiar e um só elégùn é normalmente possuído. No Novo Mundo, não existindo essa coletividade familiar, o orixá tomou 


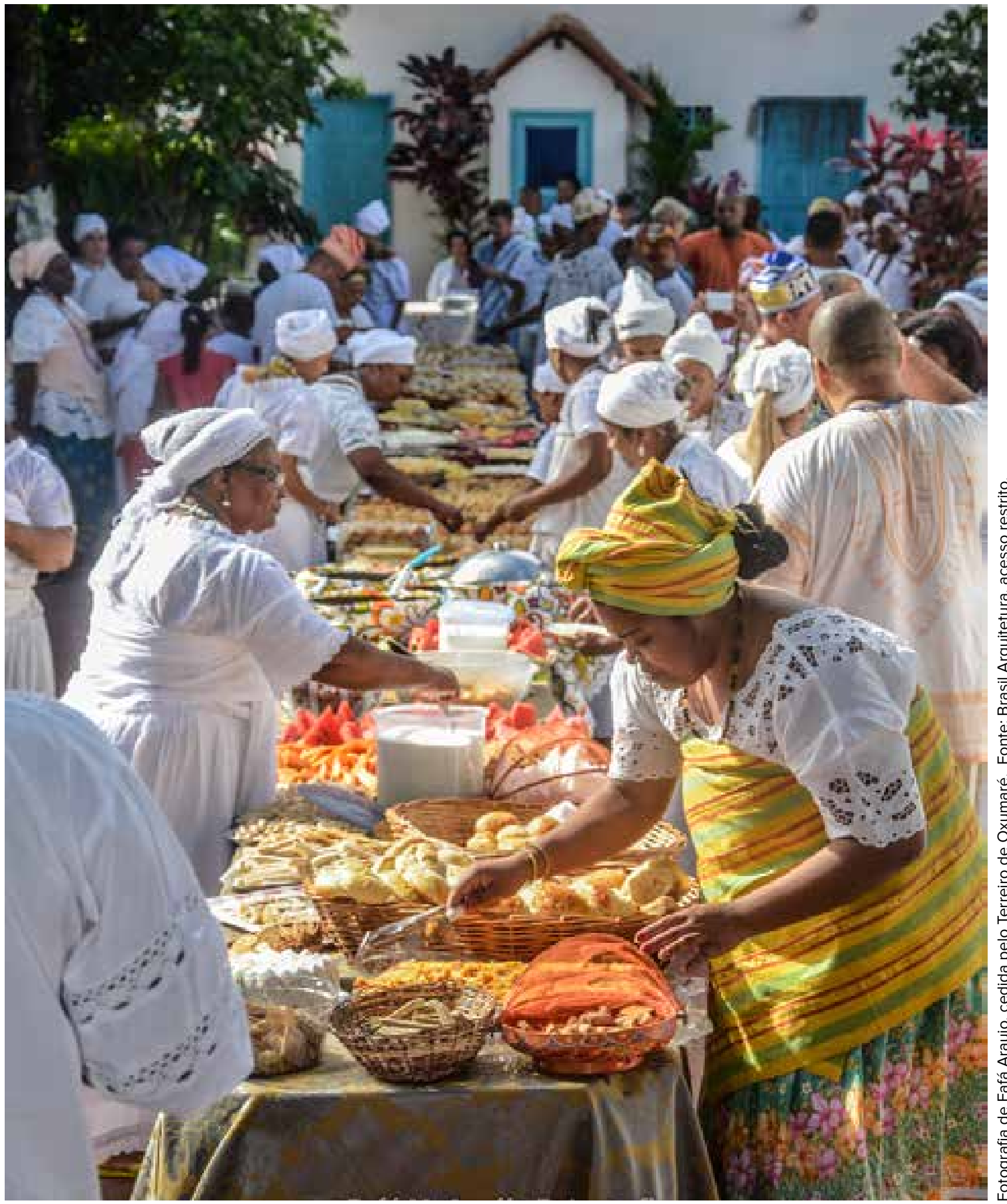

Figura 09: Imagem do cotidiano do Terreiro, café-da-manhâ.

Revista online do Departamento de Arquitetura e Urbanismo da Pontifícia Universidade Católica Puc-Rio - Rio de Janeiro Brasil Ano I - No I - ISSN 2446-7340 
um caráter individual e acontece que, durante uma mesma festa, vários 'iaôs' são possuídos pelo mesmo orixá, para a satisfaçáo própria e a de todos aqueles que cultuam esse orixá. (1997, p.74)

Lugar de aproximação, de múltiplos orixás que na casa de Oxumarê essa circunstância transparece na denominação mais completa do Terreiro:

$\mathrm{Na}$ fórmula hieronímica mais completa (Ilé Òsùmàrè Aràká Àse Ògòdó), têm destaque dois teônimos: Oxumarê designativo de um orixá considerado patrono do Terreiro - e Ogodô, nome de outra divindade, a quem se vota a cumeeira do templo principal, símbolo de sua posição eminente no mesmo espaço religioso. Entende-se que a dita fórmula identifica o referido santuário como "Casa de Oxumarê consagrada pelo (ou com o) axé de Ogodô', ou ainda "Santuário de Oxumarê com axé de Ogodô”. (SERRA, 2002, p.1)

$\mathrm{Na}$ arquitetura, essa reunião de orixás se expressa nas muitas "casas de santo" e, até na inusitada condição da existência de quatro cozinhas em um único conjunto edificado. Para compreender esse aparente "excesso" é importante saber que "para o candomblé, comer é um ato sagrado". (LODY In: CARNEIRO, p.172).

Dentro dessa perspectiva é que se pode reconhecer a manutenção das quatro cozinhas distintas na transformação em curso: a de Oxalá e dos participantes dos ritos de iniciaçáo, sem fortes temperos ou pimenta; a de Exu, que mantêm o fogáo à lenha para preservar o fogo como elemento ativo na cocção; a de Omolu, onde se realizam as comidas também dos outros orixás, dentre eles Oxumarê, Iansã, Yeman- já, Ogum, Xangô, Oxum; e a cozinha coletiva, que atende o cotidiano da casa e na qual podem adentrar também os nâo iniciados (DA MATA, 2018).

Aqui começam a se delinear as razóes que autorizam ou não as transformaçóes, pois, se por um lado há situações em que a preservação exige manutenção material (como nas casas de santo, ou no fogáo à lenha para Exu, ou mesmo na necessidade de manter a retirada da água do poço de modo manual e não mecânico), por outro lado, a renovação material é bem-vinda, como, por exemplo, na substituição dos edifícios com funçóes laicas, permitindo acessibilidade por meio de elevadores. Quem esclarece é Bàbá Leandro, ao afirmar que todo espaço sagrado deve preservar a energia em movimento, incluída aí a energia de quem participa do culto.

Um aspecto relevante em relação à arquitetura é a convicção de que o assentamento é um gesto sagrado:

Para levantar um barracão há regras especiais a observar. Em geral, a construção está entregue a um mestrede-obras, nunca a um engenheiro, e, depois de cavado o alicerce, realiza-se uma imponente cerimônia, em que o chefe do candomblé deposita ali um pouco da água dos axés, bicho de pena, moedas correntes, jornais do dia, águabenta, flores. (...) O fato de haver tais coisas sob os alicerces da casa foi a maior impossibilidade que se opôs ao desejo de ampliar o barracão das festas do candomblé do Engenho Velho, já insuficiente para conter a enorme multidão queali acorre durante os festejos anuais. (CARNEIRO, 2008, p.38) 
Em relação a essa compreensão de Carneiro, Bàbá Egbé expóe que o impedimento não é exatamente em relação à profissão, mas à aceitação e ao respeito necessário da parte de quem participa da construção, sobretudo da fundação, do gesto sagrado necessariamente presente no momento de se iniciar a obra.

Essa compreensão é determinante para os arquitetos. Afinal, não se pode simplesmente deslocar certos assentamentos. No projeto em desenvolvimento, por exemplo, um pequeno elemento anexo ao barracão se manterá como exceção em relação às retificaçôes em curso. Corresponde a um dos assentamentos de Exu. Acompanhar Bastide permite confirmar e reconhecer a relevância dessa singular manutenção:

Naturalmente, cada candomblé é obrigado a se adaptar ao sítio em que está construído, no alto de uma colina, no flanco de uma elevação; e também as dimensôes às vezes extensas, outras vezes mais restritas, do terreno que possui. Haverá, pois, variações em sua construção. Todavia, todos os que pertencem às naçóes iorubás têm caracteres comuns. Em primeiro lugar, a existência de pelo menos dois Exu. O primeiro se encontra situado numa casinhola perto da porta de entrada, vela sobre o candomblé, abre e fecha-lhe as portas, é de certo modo o porteiro local. Não tem temperamento fácil, pelo contrário é muito ciumento e até mesmo maldoso; por isso, para impedi-lo de sair, sua casa é fechada a cadeado e todo visitante, para que sua cólera não se desencadeie, deve lhe oferecer, ao entrar, um presentinho: charuto, pedaço de fumo de rolo, alguns níqueis. O segundo está enterrado no

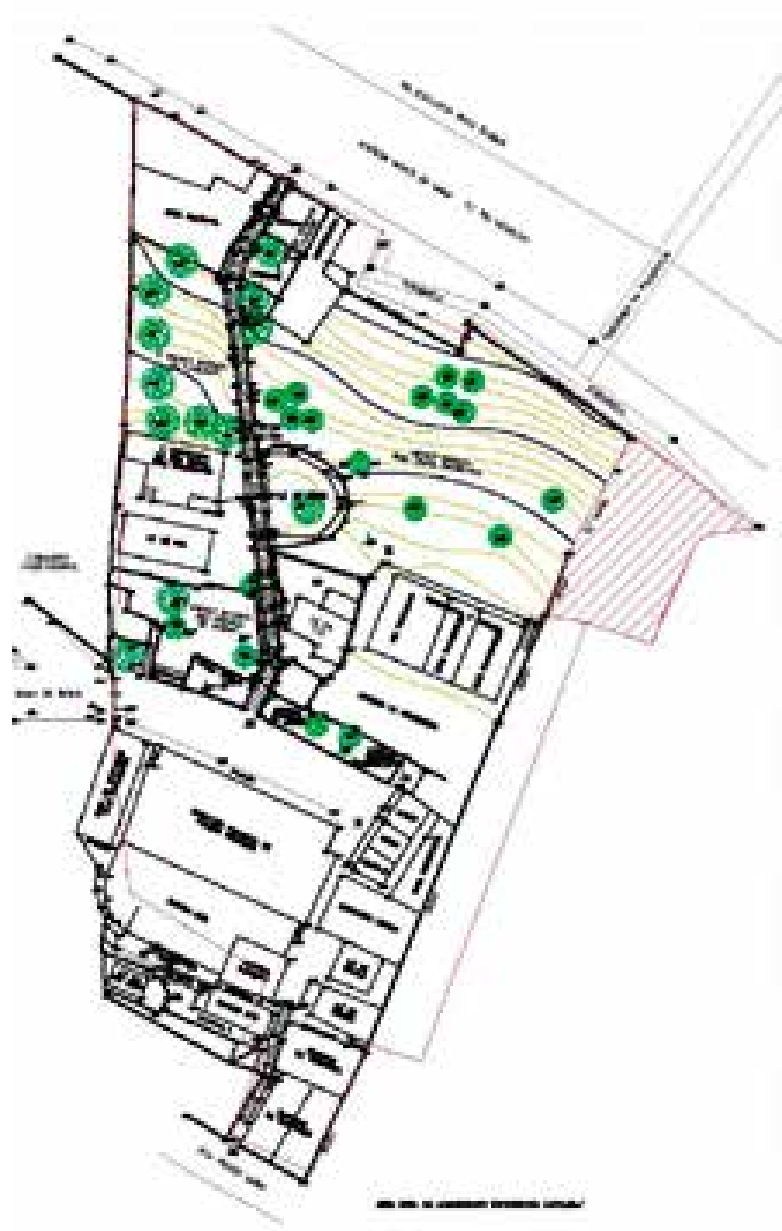

Figura 10: Levantamento

limiar da casa principal ou aninha-se atrás da porta da entrada; recebe o nome de 'comprade', o que indica que, ao contrário do outro, não é mau sujeito. Protege a casa e seus habitantes, naturalmente sob a condição de receber o que lhe é devido. (BASTIDE, 1978, p.71)

O levantamento (figura 10), já incorporadas às decisões de construir, demolir, manter, visto após a compreensão inicial do contexto sagrado, finalmente começa a ser revelar. 


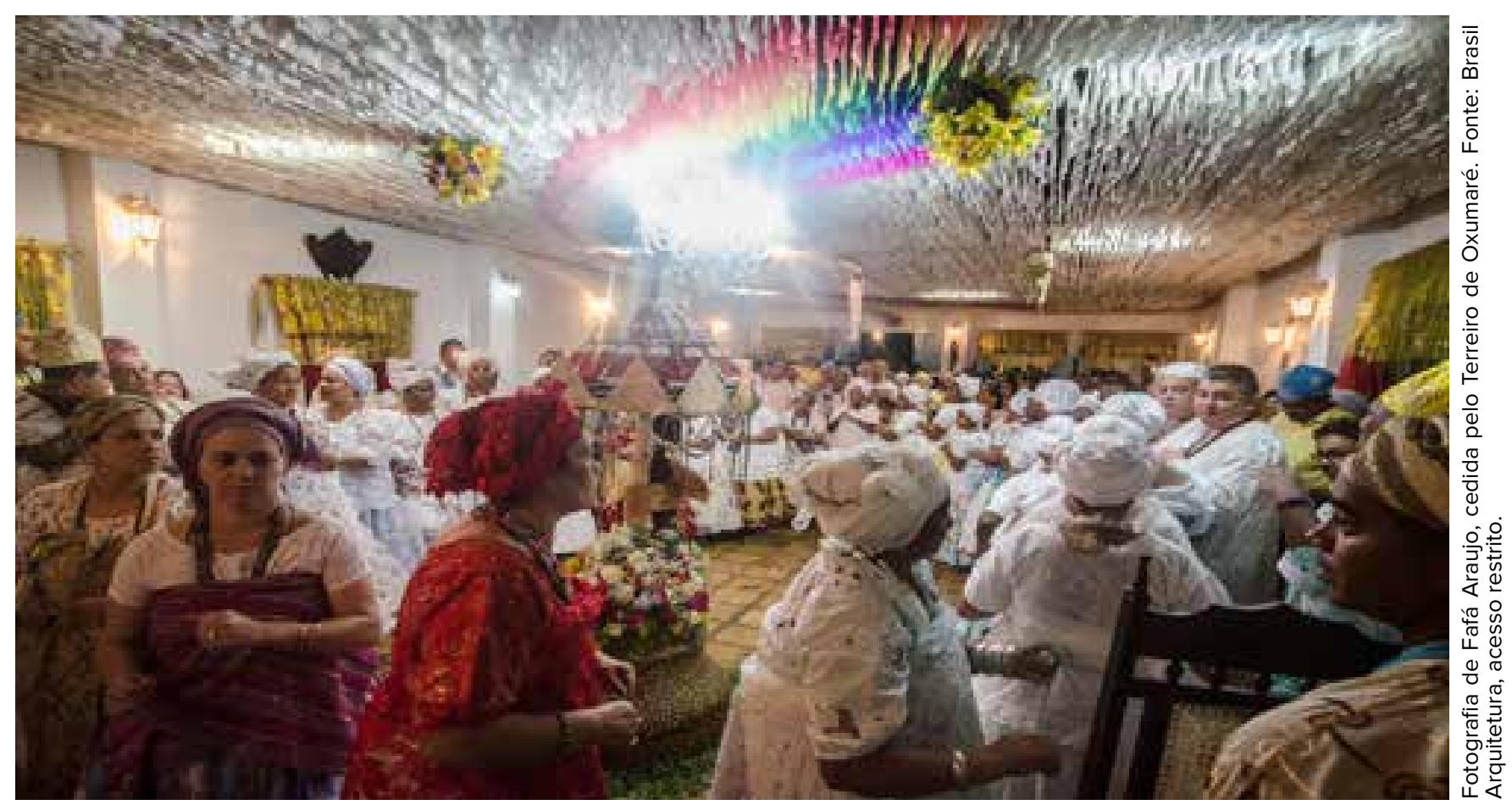

Figura 11: dia de rito no Barracão

E, sobretudo, permite reconhecer que a arquitetura aqui convoca uma ação de quem se permite saber "que os deuses sem Deus / Não cessam de brotar, nem cansam de esperar”. E que será justamente essa força sagrada (figura 11), irredutível à pura racionalidade, que preservará o movimento da vida sem destruir as razóes que animam essa mesma vida - razáo de toda e qualquer arquitetura que mereça ser reconhecida como tal. 


\section{Notas de fim:}

1. Agradeço aos arquitetos Marcelo Ferraz, Francisco Fanucci e Roberto Brotero a criteriosa apresentaçáo do projeto e a possibilidade de encontro com Bàbá Egbé Leandro Encarnação da Mata, que generosamente me permitiu compreender aspectos sagrados envolvidos na transformação arquitetônica.

2. Notícia do site do governo Portal Brasil publicado em 27/11/2013. Terreiro Ilê Axé Oxumarê é reconhecido como patrimônio cultural. Disponível em: http://www. brasil.gov.br/cultura/2013/11/terreiro-ile-axe-oxumare-e-reconhecido-como-patrimonio-cultural. Acesso em abril de 2018.

3. Notícia do site do Jornal Correio24horas publicado em 14/10/2016. Terreiro centenário da Federação, Casa de Oxumarê passará por reforma. Disponível em: http:// www.correio24horas.com.br/noticia/nid/terreiro-centenario-da-federacao-casa-de-oxumare-passara-por-reforma. Acesso em abril de 2018.

4. Memorial do projeto. Disponível em: http://brasilarquitetura.com/\#. Acesso em abril de 2018.

5. Quem é ateu e viu milagres como eu / Sabe que os deuses sem Deus / Não cessam de brotar, nem cansam de esperar / E o coração que é soberano e que é senhor / Não cabe na escravidão, náo cabe no seu não / Não cabe em si de tanto sim / É pura dança e sexo e glória, e paira para além da histórial Ojuobá ia lá e via / Ojuobahia I Xangô manda chamar Obatalá guia / Mamãe Oxum chora lagrimalegria / Pétalas de Iemanjá Iansã-Oiá ia / Ojuobá ia lá e via / Ojuobahia / Obál É no xaréu que brilha a prata luz do céu / E o povo negro entendeu que o grande vencedor / Se ergue além da dor / Tudo chegou sobrevivente num navio / Quem descobriu o Brasil? / Foi o negro que viu a crueldade bem de frente / $E$ ainda produziu milagres de fé no extremo ocidentel Ojuobá ia lá e via / Ojuobahia / Xangô manda chamar Obatalá guia / Mamãe Oxum chora lagrimalegria / Pétalas de Iemanjá Iansã-Oiá ia / Ojuobá ia lá e via / Ojuobahia / Obá / Ojuobá ia lá e via / Quem é ateu.

Disponível em: https:/www.youtube.com/watch?v=-
3faMa5dLAwQ. Acesso em abril de 2018.

Essa música foi lembrada por Marcelo Ferraz na segunda entrevista sobre o projeto, ocorrida com Roberto Brotero no dia 02 de abril de 2018. A primeira ocorreu em 08 de fevereiro de 2018 com Francisco Fanucci, Marcelo Ferraz, Roberto Brotero e Ana Vaz Milheiro. Alguns termos usados na letra merecem atenção: $O b a ́$ - rei, termo empregado para designar os ministros de Xangô (BASTIDE, 1978, p.287);

Pesca do Xaréu - conserva tradiçóes africanas na Bahia, ver fotografias de Pierre Verger, cena de Barravento, filme dirigido por Glauber Rocha (1962), e curta-metragem Xaréu dirigido por Alexandre Robatto Filho (1954).

6. Na linguagem dos terreiros, segundo o laudo antropológico que acompanhou a solicitação de tombamento (SERRA, 2002, p.1) Ilê Axé equivale em tradução a "Santuário de Oxumarê".

7. Caderno Casa de Òsùmàrè, Brasil Arquitetura, agosto de 2017, acesso restrito.

8. Esse grupo de trabalho foi instituído pelo IPHAN em 2015, e atua na preservação do patrimônio cultural de bens relacionados aos povos e comunidades tradicionais de matriz africana. Grupo de Trabalho Interdepartamental para Preservação do Patrimônio Cultural de Terreiros (GTIT). Disponível em: http://portal. iphan.gov.br/pagina/detalhes/1311. Acesso em abril 2018

nistério de Educação, Cultura e Esportes da Espanha, Centro de Patrimônio Mundial da UNESCO, ICOMOS e a Organizaçáo de Cidades Patrimônio Mundial.

9.Terreiro da Casa Branca ou Ilê Axé Iyá Nassô Oká, foi primeiro terreiro tombado pelo Iphan em 1984, data que foi reconhecido oficialmente como patrimônio histórico e etnográfico do Brasil.

Fonte: http://portal.iphan.gov.br/ba/noticias/detalhes/3221/terreiros-do-brasil-guardioes-de-tradicao-milenar. Acesso em abril de 2018. 
10. Livro Histórico: Insc. n 504, de 14/8/1986; Livro Arqueológico, Etnográfico e Paisagístico: Inscr. no 93, de 14/08/1986; Processo: 1067-T-82. Fonte: Arquivo Noronha Santos.

11. Livro Histórico: Insc. no 559, de 28/7/2000; Livro Arqueológico, Etnográfico e Paisagístico: Inscr. $n^{\circ}$ 124, de 28/07/2000; Processo: 1432-T-98. Fonte: Arquivo Noronha Santos. Disponível em: http://portal. iphan.gov.br/ans.net/. Acesso em abril de 2018.

12. Memorial do projeto. Disponível em: http://brasilarquitetura.com/\#. Acesso em abril de 2018.

13. Depoimento gravado, em encontro ocorrido no escritório do Brasil Arquitetura no dia 17 de abril de 2018.

14. Trecho do texto de Apresentação da Casa de Oxumarê.

Disponível em: http://www.casadeoxumare.com. $\mathrm{br} / \mathrm{var} / \mathrm{www} / \mathrm{html} / \mathrm{cas}$ adeoxumare.com/web/index. php/2015-07-12-20-45-13. Acesso em maio de 2018.

15. Depoimento gravado, em encontro ocorrido no escritório do Brasil Arquitetura no dia 17 de abril de 2018.

16. Vila Nova Esperança, Salvador, BA. Disponível em: http://brasilarquitetura.com/\#. Acesso em abril de 2018.

17. Caderno Casa de Òsùmàrè, Brasil Arquitetura, agosto de 2017, acesso restrito, p.9.

18. Calendário Religioso. Disponível em: http://www. casadeoxumare.com.br/index.php/janeiro. Acesso em: fevereiro de 2018.

19. Calendário Religioso. Disponível em: http://www. casadeoxumare.com.br/index.php/janeiro. Acesso em: fevereiro de 2018. 


\section{Referências Bibliográficas:}

BASTIDE, Roger. O candomblé da Bahia: rito nagô. Tradução de Maria Isaura Pereira Queiroz. 2, ed. São Paulo: ed. Nacional; Brasília: INL, 1978.

ALMEIDA, Eneida de; BOGÉA, Marta. Patrimônio como memória, memória como invenção. Arquitextos, Sáo Paulo, ano 17, n. 195.04, Vitruvius, ago. 2016 <http://www.vitruvius.com.br/revistas/read/arquitextos/17.195/6175>.

CARNEIRO, Edison. Apresentação e Notas de Raul Lody. Candomblés da Bahia. 9 ed. São Paulo: editora WMF Martins Fontes, 2008.

CERTEAU, Michel de. A invenção do cotidiano. 1. Artes de fazer. Petrópolis: Vozes, 1994.

IZQUIERDO, Ivan. Memória. Porto Alegre: Artmed, 2011.

VERGER, Pierre Fatumbi. Orixás: deuses iorubás na África e no Novo Mundo. Tradução Maria Aparecida da Nób. 5 ed. Salvador: Corrupio, 1997.

\section{Documentos de acesso restrito consultados:}

BRASIL ARQUITETURA. Caderno de apresentação do anteprojeto para Casa de Òsùmàrè, agosto 2017.

INSTITUTO DO PATRIMÔNIO HISTÓRICO E ARTÍSTICO NACIONAL. Parecer Técnico no $0547 / 2017$.

SERRA, Ordep (Coord.) Laudo antropológico da Casa de Oxumarê Ilé Òsumàré Árakà Àsè Ógódó, 2002.

\section{Entrevistas e depoimentos:}

FERRAZ, Marcelo, FANUCCI, Francisco, BROTERO, Roberto. Entrevista concedida a Marta Bogéa. São Paulo, março/abril de 2018

DA MATA, Bàbá Egbé Leandro Encarnação. Depoimento gravado em encontro ocorrido em São Paulo, 17 de abril de 2018 .

\section{Sites visitados:}

http://www.casadeoxumare.com.br

http://www.brasilarquitetura.com

http://portal.iphan.gov.br 